\title{
THE NOTION OF LIBERALISATION ON THE ANTI-HADITH MOVEMENT AND ITS IMPACT ON SOCIETY
}

\author{
Abur Hamdi Usman ${ }^{1}$, Rosni Wazir ${ }^{1}$, Zanariah Ismail ${ }^{2}$ \\ ${ }^{1}$ Faculty of Islamic Civilization Studies, International Islamic University College \\ Selangor (KUIS), 43000, Kajang, Malaysia. \\ ${ }^{2}$ Universiti Putra Malaysia, Department of Human Development and Family Studies, \\ Serdang, Malaysia. Email: zanariah_i@upm.edu.my \\ Corresponding Author: Abur Hamdi Usman. Department of Dakwah and Usuluddin, \\ Faculty of Islamic Civilization Studies, International Islamic University College \\ Selangor (KUIS), 43000, Kajang, Malaysia. Tel: (+60) 01128088797. Email: \\ aburhamdi@kuis.edu.my
}

\begin{abstract}
In the $18^{\text {th }}$ century, the West pioneered a surge of modernisation as a force of imperialism created the idea of Islamic-oriented liberalisation in the West's conquest countries. This Western European-led modernisation stems from the network of a capitalist economy, technological issues, social influence, and changes in political power worldwide. This perpetuated questions among Muslim philosophers about the weakness of Muslims and their decline, compared to the exponential growth of Western Civilisation. At the same time, rationalism and historical criticisms aided the reign of colonialists, becoming the prime motivation of European Orientalists to take a critical approach towards the study of hadiths in Islamic countries. There is a scarcity of Muslim scholars who are influenced and fascinated by Western Orientalists' 'new' Islamic discourse and thinking, who then adapt them as an alternative solution to Muslim issues worldwide. Therefore, this article elaborates on Islamic liberalisation efforts, especially those that touch on the issues of hadiths raised by a group well-established as the Anti-Hadith Movement (AHM). Among the issues raised include the relevance of the hadiths' teaching in a modern era as well as the authority of hadiths play-acting as a medium driving progress or regression. The outcome of the study finds that AHM invites implications and confusion to society in the form of Western thinking, as well as the civilisation that shapes Islamic modern thinking.
\end{abstract}

Keywords: Liberalisation; the Anti-Hadith Movement (AHM); Hadith; Society; Malaysia

\section{(IDEA LIBERALISASI DALAM GERAKAN ANTI HADITH DAN IMPAKNYA KEPADA MASYARAKAT)}

\begin{abstract}
ABSTRAK
Menjelang abad ke-18, arus pemodenan yang diterajui oleh Barat sebagai kuasa imperialis telah menimbulkan idea liberalisasi ajaran Islam di negara-negara yang
\end{abstract}


Published by Faculty of Islamic Civilization Studies, KUIS

dijajah. Ini bertitik tolak dari rangkaian perhubungan ekonomi kapitalis, isu teknologi, sosial dan perubahan kuasa politik di seluruh dunia yang dikepalai Eropah Barat. Ini mendorong persoalan di kalangan pemikir Islam mengenai kelemahan umat Islam serta kemundurannya berbanding perkembangan pesat Tamadun Barat. Dalam pada itu, fahaman rasionalisme dan kritikan pensejarahan dengan dibantu oleh pentadbiran kolonialis, telah menggerakkan Orientalis Eropah untuk memberikan perhatian kritikal terhadap pengajian hadis di negara-negara Islam. Tidak sedikit sarjana Muslim yang terpengaruh serta terpesona dengan wacana dan pemikiran Islam 'baru' yang dikemukakan oleh orientalis Barat, lalu mengadaptasikannya sebagai solusi alternatif kepada permasalahan umat Islam global. Justeru, artikel ini menghuraikan usaha liberalisasi ajaran Islam, khasnya menyentuh persoalan ajaran hadis yang dikemukakan oleh golongan yang dikenali umum sebagai Gerakan Anti Hadis (GAH). Antara persoalan yang ditimbulkan adalah relevansi ajaran hadis dalam era moden, autoriti hadis serta hadis berperanan sebagai medium memacu kemajuan ataupun sebaliknya. Hasil kajian mendapati GAH ini mengundang pelbagai implikasi dan kekeliruan kepada masyarakat dalam keadaan pemikiran Barat dan tamadunnya menjadi pencorak utama dalam arus pemikiran moden Islam.

Kata kunci: Liberalisasi;Gerakan Anti Hadith; Hadis; Masyarakat; Malaysia

Received: Sepetember 15, 2017 Accepted: October 26, $2017 \quad$ Online Published: December 30, 2017

\section{Introduction}

The discourse of the hadith and its studies in the Islamic world have continued for more than 1400 years, reflecting of the confidence of Muslims towards religious life (Abou-Bakr 2003). The hadiths, as the inheritance of the Prophet Muhammad (pbuh), motivated his companions to strive towards ensuring that the hadiths can be sustained, preserving them from any elements of lies and betrayal (Duderija 2009). This was continued by the Followers (Tabi'un) and Followers of the Followers (Tabi Tabiin). They introduced the chain of narration (isnad) system and various disciplines of hadiths through ensuring the credibility of the hadith writers and the validity of the hadiths being absolute (Baraka and Dalloul, 2014). By the end of the $17^{\text {th }}$ century, Muslims received the hadiths' teachings and learning through the words of scholars. Furthermore, Muslim scholars have delivered the teachings of Muhammad (pbuh) without disputing the narrations (Demirel, 2011). However, the European imperialisation in the $18^{\text {th }}$ century, led by countries including Great Britain, France, Italy, and the Netherlands, disrupted the Islamic education system in Islamic countries (Hilgendorf, 2003). These disruptions created a secular education system by separating academic subjects from its religious elements found in its content, especially morals and Islamic law (shari'a) (Syed, Özbilgin, Torunoglu, and Ali, 2009).

The westernised policy of the education system inculcated in Islamic countries indirectly created a dichotomy between modern and traditional academic studies (Herrera, 2004). The situation was exacerbated when the younger generation of Muslims were offered education scholarships in Western countries, rather than opening more Islamic study centres with orientalists serving as the main instructors. The resulting alumni of this Western education normally return to society as Muslim modernists, who then bring along 'new' ways of thinking and are more open to issues 
involving the integration of Western and Islamic civilisations. Such an open paradigm is their reflection of being blinded by Western civilisation, which is physically more advanced and modern, to the point that they claim the contributions and works of Muslim scholars are far behind and outdated (Adonis, 1994; Hasan, 1980; Arkoun, 1994). This includes an attempt to adapt the element of enlightenment by regarding the mistakes and weaknesses of Muslims as the result of their dependency on past scholarly works (Aydin, 2007).

This movement is very critical for Islamic knowledge traditions, because it produces a group of Muslims who think about the relevance of the hadiths to Muslims. This includes disputing the rationale and scientific values contained in the hadiths. The concept of liberalisation is synonymous with this movement, which is known as the Anti-Hadith Movement (AHM), and is alike to other liberal movements, including the overwhelming demand for human rights and the emancipation of Muslim women from the wellbeing of Islam (Sikander, 1991).

Hence, this article points to the pathetic irony that the anti-hadith argument is often based on subjective and naively selected hadiths, to the effect that the Prophet (pbuh) or someone else from the earliest authorities had forbidden or discouraged the transmission of hadiths from the Prophet (pbuh). Besides the intrinsic irrationality of this point of view, this anti-hadith reveals, on closer historical examination, to be itself a direct product of the hadith movement. Furthermore, if all hadiths are given up, what remains but a time gap of fourteen centuries between us and the Prophet (pbuh)? Moreover, in the vacuity of this gap, not only must the Quran slip from our fingers under our subjective whims, for the only thing that anchors it is prophetic activity itself. Furthermore, even the very existence and integrity of the Quran and the existence of the Prophet (pbuh) himself becomes an unwarranted myth (Rahman, 2008).

\section{The Concept and History of Liberalisation in Muslim Society}

The term 'liberalisation' comes from the English word liberal, which means the freedom to think without bias toward any beliefs and faiths (Anon, 2007). Meanwhile, the word 'liberalism' is used widely in Europe at the end of the $19^{\text {th }}$ century regarding interpreting the political ideology at the time (Kymlicka and Opalski, 2002; Gould, 1999). Although seen as one of the political ideologies, liberalism comes with various interpretations, but it still prioritises tolerance, elevating individual rights and freedom to ensure that a pluralistic life prevails (Fawcett, 2014). This stems from the issue of religion, which is the degree of control from the church towards society in the aspects of politics and the economy, rather than the weakness of its management system and the administration of the church itself. This encourages the reformation of the church's institutes in Europe (Cameron, 2012; Bossy, 1970; Chadwick, 1990), which also received support from society. Thus, society demands freedom from the clasp of the church, which has the power to collect tax from its people and intervene in the nation's political affairs. Therefore, the peak of reformation is the separation of the church from administration and the nation, because of society's anger towards the weakness of the church itself (Abdul Rani, 2001).

The idea of the freedom of society towards religious tradition began to spread in Muslim countries through the exposure of education and the orientalists' propaganda combined with the imperialist powers of the Western colonials (Fore, 2002). Most Muslim children with potential were sponsored by the latter to receive a Western education, because of their strategy to continue their dominance over Muslim 
Published by Faculty of Islamic Civilization Studies, KUIS

thinking. Among the earliest Muslim scholars who put forth the notion of liberalisation in Islam was Asaf Ali Ashgar Fyzee (d. 1981), who created the idea of 'liberal Islam' (Kurzman, 1998). Fyzee offered an open perspective by concentrating on Islamic modernisation, stressing on the reinterpretation of Islam and Islamic laws, such that they are consistent with modern times (Daftary, 1984). Moreover, for him, the teaching of decree needs to be reinterpreted by accounting for newly discovered diversities of theories, as found in the history and science disciplines (Fyzee, 2008). The thinking and idea put forth by Fyzee is an effect influenced by Christianity and other Western religious doctrines. For that purpose, he dreamt of a new sect in the Muslim community, as had happened in Christianity resulting from the church's reformation, which is known as Muslim Protestant or liberal Islam (Nurdin, 2005). The main characteristics that became fundamental ensure that Islam can be adapted to a modern lifestyle, rather than dismissing the value of jumud in religion; thus, an adaptation can be realised (Wan Ramli, 2014).

The paradigm and protest towards the religious tradition also influences some of the Muslim scholars into defying and questioning the validity of the teachings of the hadiths in society. This group of people have self-proclaimed that they are religious modernists, simultaneously known as Quranist (Ahl al-Quran) or the AntiHadith Movement (AHM), and they are very expressive, owing to their educational status and close relationships with colonials. Because they were influenced by the idea of a hadith put forth by orientalists (Alsehri, 2014) like William Muir (d. 1905) and Ignaz Golziher (d. 1921), they have been encouraged to dispute the practice and beliefs that lean on the hadiths, regarded as a stumbling block towards Muslim progress. Among the earliest members of AHM are Chiragh Ali (d. 1895), Sayyid Ahmad Khan (d. 1898), Abdallah Chakrawali (d. 1930), and Ahmad Din Amritsari (d. 1936) (Darussamin, 2016). To enable the adaptation of Islam with the current demands, AHM proposed that only the Quran was accepted as the resource of legislation and way of life (Bańkowska, 2007). Therefore, the interpretation towards a decree as a system of life must be guided by humanistic ideas; for example, rationalism, science principles, and religious-based ethics. The same goes with the idea supported by Muhammad Aslam Jayrapuri (d. 1955) and Mistri Muhammad Ramadan (d. 1940), who challenged the scientific accounts and isnad of the hadiths as those that are devoid of worshipping values. Therefore, they claimed that isnad was heavily falsified and that its criticisms are used to determine the truthfulness and misleading nature of a hadith (Brown, 2011). In turn, through the decree of the Quran, Allah has allocated a complete set of rules and regulations and a perfect system for man, while the rest is left to the humans' own devices and wisdom based on their rationale (Brown, 2009).

The aspect and idea of liberalisation put forth by AHM does not differ much from the concept and thinking raised by the liberal Muslims (Nagata, 1997). It is assumed by AHM that Muslims are experiencing phases of decline and weakness because they are too dependent to the religious traditions, especially concerning the teaching of hadiths. For them, Muslims need to emulate the aspect of modernisation put forth by the west, abandoning the traditional principles inherited through hadiths and past literature (Faridi, 2008). Such a way of thinking contrasts with Islamic history, which clearly does not point to any improvement or progress; examples include the Dark Era to the Renaissance, the Enlightenment, Modernism, and PostModernism. Therefore, an understanding that takes its guidance from a new concept is better than the old one, or the new one must replace the old, which is part of the 
framework of thought that stems from the modernism philosophy (al-Attas, 2007; Buang, 2016, 40).

\section{The Emergence of the Anti-Hadith Movement (AHM) in Malaysia}

Fundamentally speaking, the concept and idea of liberalisation supported by AHM are synonymous with other Muslim movements. This includes issues concerning religious authorities, human rights, rationalisation values, and women's rights, leading to the negation of the role of prophetic traditions in the lives of Muslims (Brown, 2009; Suliaman, 2009). Nonetheless, AHM can be classified into three main groups based based on their movements:

i. The people who rejected entirely the hadiths of Muhammad (pbuh) and claimed themselves as Muslim modernists and Ahl al-Quran (Khan, 2016; Musa, 2010). They accepted and believed in the theory raised by orientalists, like Muir and Goldziher, about the doubts surrounding the narrative system, the rationale of hadiths, and those who are Western educated.

ii. Those who refuted the hadiths that conflict with the content of the Quran directly or indirectly, together with the hadiths that are opposed to human rational values (Brown, 2013). This group is comprised of the Modernist Salafi and those who make the effort to defy the Western rationalism.

iii. The group that only receives the continuous hadiths (mutawatir) and rejects the isolated hadiths ( $\mathrm{ahad}$ ), although they fulfil the requirements of hadiths (Kadir and Othman, 2012). They are comprised of the Traditionalist Salafi and have made the effort to raise the quality of the mutawatir hadiths.

The existence of AHM in Malaysia in the early 1980s was recognised as deviant teachings (Ismail, 2010, 250; Nagata, 2004). The majority of AHM advocators have published their books and writings through the medium of electronics as the medium of sharing and dissemination of ideas (Nordin, Abdullah, and Mansor, 2013). Among the literature that focuses on the idea of liberalisation, especially those that touch on the authority of hadiths are (Suliaman, 2009): Hadis Satu Penilaian Semula and Hadis Jawapan Kepada Pengkritik by Kasim Ahmad, Pendedahan Kebenaran Adalah dari Tuhanmu - Hadis di dalam al-Quran by Idris Abdul Rahman, Bacaan by Othman Ali, The Computer Speaks - God's Message to the World by Rashad Khalifah. The same goes through blogs or websites, especially kassimahmad.blogspot.com and http://www.themalaymailonline.com/opinion/farouk-a.-peru.

Based on the list above, clearly there is a publication of several books and websites that contain the idea of AHM, other than the social media platform to enable their interaction with the public. Among the main purposes for the use of the websites were to assist in teaching, research, thesis writing, and writing assignments (Karim and Hazmi, 2005). Despite the continuing bureaucratisation of Islam, in matters of education, law courts, endowed land, and taxes, the government of Malaysia cannot completely eradicate deviant movements, whether the Sufi Al-Arqam or anti-Hadith groups, but makes use of its own power to define what is heretical and hence to punish (Nagata, Lee, and Ackerman, 1998, 141). 


\section{Published by Faculty of Islamic Civilization Studies, KUIS}

\section{Idea of Liberalisation in the Anti-Hadith Movement (AHM)}

The detailed discussion of the concept of liberalisation in (AHM), reveals several key issues of liberalisation fought based on the evaluation on the products and the active movement. Among them are:

a) Liberalisation in the interpretation of the Quran

AHM claims that the interpretation of the decree is similar to the inspirations (Choudhury, 2001). Certainly, the text of the Revelation may be appropriated by differing contexts, which unashamedly places its own frames of references on the text, and this is what the anti-hadith movement seems to want to accomplish (Sikander, 1991). Therefore, it is held that everyone can be inspired; but at the same time, it allows people to fight and interpret the Quran. Other than that, AHM also holds the concept of Western rationalism in justifying their own respective rationale to interpret the Quran. For AHM, Quran is only an ordinary book in Arabic, thus they feel that its readers can interpret based on their own understanding (Ahmad, 1986, 130-131).

b) Liberalisation of views and rationale towards the hadiths

The detractors of the prophetic traditions (al-Sunnah) reject the Prophet's authority to bring 'extra-Qur'anic teachings', while adhering to the doctrine of the Quran because they maintained that the Quran is sufficient to guide human life (Sulaiman, Jamsari, and Nizah, 2013). This is because AHM sees the hadith's interpretation about the Quran as only confined to the era. The change of the era and modernisation has become the platform to AHM to place hadiths as a teaching of the past (Ahmad, 1986, $15)$.

The same can be applied to the claim that hadiths are merely additional to the teaching of the Quran. Moreover, AHM makes the conclusion that a lot of hadiths contain the teachings from the already-revised Torah; for example, death sentence for deviants, stoning to death adulterers, etc. In addition, AHM believes hadiths are the root cause of the disintegration and decline of Muslims, other than accusing Muhammad (pbuh) as being irresponsible towards the emergence of hadiths after the passing of the hadiths. Therefore, they suggested that all hadiths opposing to the Quran are rejected, and that there are superstitious beliefs included in Islamic teaching through hadiths (Ahmad, 1986, 15). In summary, the hadith is not an authentic source of Shari'ah. It could strengthen anti-hadith propaganda and Muslims who do not have deep knowledge about the sources of Shari'ah and the hard and sound work done by hadith Scholars in preservation of the Sunnah of the Prophet (pbuh) might get the false impression that the Quran should be sufficient for interpreting and implementing Islamic tenets in human socio-economic activities. Furthermore, where the Quran is not explicit on any matter, one is free to undertake any activity (Farooq, 2014; Ayub, 2012,9).

This clearly depicts how open AHM is in criticising the second legislation after Quran. They even did not endorse the hadith's narration through memorisation, which was thought to be a lie and impossible for humans to memorise thousands of hadiths that have a network of narrators. Therefore, Malaysia publicly warned of a deviationist anti-hadith movement that denied Prophetic traditions and referred to the Quran without theological knowledge (Müller, 2016). 
Other than those, AHM also attacks from the perspective of history and hadiths by stating that the duration of time that the hadiths are written clearly demonstrates the weakness of the chain of transmission (sanad) and text (matan). The Prophet Muhammad (pbuh) debated the forbidden rules about the writing of hadiths today. Therefore, scholars have exploited the collection of hadiths by creating them and relating them to Muhammad (pbuh) (Sudi, Wazir, Usman, Nasir, Ismail, Salleh, and Rahman, 2016).

c) Liberalisation in the criticisms towards the Prophet Muhammad (pbuh)

Liberalisation in regards to criticisms towards the Prophet Muhammad (pbuh) includes perceiving Muhammad (pbuh) as a fortune teller, following his ability to perform miraculous things in several incidents. The applies toward the claim about the prohibition in differentiating the status of the Prophet (pbuh) with that of other Apostles. This is because they regarded the Apostles as ordinary people that can also make mistakes. Furthermore, there is the special prayer (selawat) for the Prophet based on extreme worshipping, and this is prohibited (Ahmad, 1992, 36). Additionally, they claim that the miracles of the Prophet (pbuh) were denied in the Quran. According to their logic, it is impossible for the Apostles, scholars, and pious people to interrupt to ask for lighter punishments on sinners. Again, AHM claimed that the Prophet's power is only limited to the Quran, and it is only functional to be delivered to the society. Due to the over-dependency on the Prophet (pbuh), society has over-worshipped him and the companions, and they lag behind modernisation. By contrast, Muhammad (pbuh) was accused as being flawed, thus he cannot become the role model and spread goodness to others. These groups were labelled anti-hadith, by ignoring the deeds and sayings of the Prophet (pbuh) in favour of the original Quranic text (Nagata, 1997).

\section{d) Liberalisation in the Islamic faith}

There is the claim made by the AHM that one will enter Heaven if he or she can utter the two declarations of faith (shahadah) before his or her passing. Therefore, everyone will assume that they are free to do anything if they are able to utter the shahadah at the end of their time. The irony is AHM has challenged the selawat to Muhammad (pbuh) as the Prophet. AHM opines that shahadah is not the determinant to one's sense of Islam. This is very much against the concept of shahadah practised by Muslims for so long. Additionally, they also claimed that the story of Jesus (pbuh) being lifted to the sky was a mere creation. The same goes with the arrival of Imam Mahdi and Dajjal as myths because they are not stated clearly in the Quran. They also refused the concept of life after death, because it cannot be explained scientifically. Another subject of criticism is the issue of predestination (Qada' and Qadar), where the community believes in a bad deed as fate.

\section{e) Liberalisation in the implementation of Islamic worship}

It is believed that prayer is not the mainstay of religion. Therefore, the pillar of religion is Oneness of Allah (Tawheed). Muslims believe that the pillar of religion is tawheed and nothing else. The same goes with the claim that the order to perform prayer was received by the Prophet Abraham before Muhammad (pbuh). Furthermore, the method of prayer understood by AHM is vastly different, among which is 
Published by Faculty of Islamic Civilization Studies, KUIS

remembering God and worshipping Him as another form of worship to Him. The performing of pilgrimage (hajj) is also debated, whereby the hajj does not have to be done in the month of Zulhijjah alone, whereas the hajj is only to remember the good example emulated by the Apostles (Ahmad, 1992, 41).

\section{f) Liberalisation in Islamic laws and legislation}

Liberalisation in Islamic laws and legislation includes defying that the heads and hair of women are genitalia (aurah). They suggested that Muslim women lay bare their hair because they see it as another form of human rights. Instead, AHM claimed that aurah goes so far as the parts of the bodies involved in ablution only. They also stated that there is no prohibition for men and women when shaking hands, because 'fighting' for a cause using the verses of the Quran with regards to the term 'lamastum' means being in consummation, with no touching between man and woman. Moreover, they claimed that the Islamic penal code (hudud) implementation is illogical because the scholars had misinterpreted the Quranic verses (Müller, 2015). Ironically, AHM in Malaysia equated scholars to priests (Samuri and Hopkins, 2017). They also see Islamic laws as cruel and inconsistent with modern civilisation. In the marital context, AHM allows for polygamy only when the wife cannot bear children or is sick. Therefore, AHM may be labelled as apostates. These apostasy cases include one's involvement in issues of religious conversion, deviant teachings, antiMuhammad, anti-Hadith, or anti-Quran statements, etc. (Rahman, et al., 2015, 111; Sabjan and Akhir, 2016; Spiegel, 2010).

Based on the above, AHM is very much dominated by the liberalisation framework that stems from the idea in liberalism from the West that justifies every good and bad according to their mere mind and lust.

\section{The Impact of the AHM Liberalisation towards Society}

In Malaysia, AHM is among the national interest or Muslims' faith issues (Nasohah, Laluddin, Kusrin, and Muwazir, 2012). If liberalist ideas and thinking towards AHM are allowed to disseminate, society, especially Muslims, will face a very fine and intricate moral challenge. This is because the AHM often fights policy issues and adopts the dialogue approach. Therefore, these are the implications and impacts of the dissemination of ideas of AHM liberalisation to society:

i. The Challenge towards the Shafi'ite School in the Malay world

The activities of AHM are indeed a challenge to the homogeneous teachings of Ahl alSunnah wa al-Jama'ah in Malaysia (Alwi, Bakar, and Subki, 2015). The AHM vocally stated that the interpretation of Islamic jurisprudence (fiqh) founded by Imam al-Shafi'i (767-820 CE) is subjective and narrow. In addition, they also claimed that this sect has lagged and became the reason for the weak intellect among Muslims.

The protestation against the tradition will lead to a great deal of confusion. In a world where Muslims have yet to dominate the knowledge of the Islamic tradition works (turath), movements like the AHM can shake the confidence of the people about their current belief system. By contrast, it will open a big space to the criticisms and the refusal towards the notion of the sect itself.

Imam al-Shafi'i was involved in judging and collecting the hadith, and he travelled to many places to hear the hadiths and to collect them. This role gave him the title of the defender of hadith by his great reputation that arose because of his 
arguments with the group of the anti-hadith. He argued in a very clever way about the establishment of the Sunnah during the Prophet's time and insisted that the Sunnah was based on the Quran (Saad, 1990, 8). With certainty, they would not refuse and react negatively towards him.

\section{ii. Fascination to religious interpretation according to the Western philosophy}

The majority of the AHM advocators are those who look up to Western Civilisation's values that are more modern and advanced. In turn, the religious paradigm, especially the teaching of hadiths as the stumbling block towards societal progress, is apparent in all their claims towards the hadith's study system. This stems from the Western philosophy built from the paradigm of logical empirical positivism, where every knowledge that adapts systematic methods with clear objectives is the only way of getting accurate knowledge (Managheb and Mehrabi, 2013). Meanwhile, research that is based on the sources of decree is non-scientific and it thus cannot be proven empirically, whereby everything can be understood physically using all our senses. This attitude stems from their sceptical attitude towards religion and the supernatural, other than the lack of formal Islamic education which are resourced from the turath.

\section{iii. Prioritising the Western human rights concept}

In regards to this issue, AHM is dominant in the aspect of fighting for freedom to demand for Western-oriented human rights; for example, the emancipation of Muslim women in administration, economy, and social network (Mayer, 2012). This includes questioning the various laws and authorities of Islam, because they are thought to hamper the effort of modernising women who need to have their freedom in terms of their clothing, socialising, and career, in order to reach the level achieved by women in the West. This indirectly affects the image of Muslim women who are rich with courtesy, manners, and etiquette (Shah, 2006). Additionally, human rights shown in the West prioritise individualistic needs rather than the greater good for society. Among them is the freedom to collect and reap profits without considering the lawful and the prohibited (halal and haram) in Islam (Saad, 1990), as well as the sins when it comes to managing the economy. Quality individuals clearly get a better position on this earth as Caliphs, where they are supposed to work together with other individuals.

\section{iv. The Threat towards the strength to the Malay culture}

The root of the misinterpretation and misunderstanding of the hadiths often leads to one being anti-hadith (Nazri, et al., 2016). The members of AHM are true advocates of the entire liberalist agenda. Any laws and authorities of Islam are open for debate, because they are threatened by the powerful role of Islam going against the liberalism agenda. They protested the traditional belief that placed scholars and religious people as having an absolute power in the true Islamic interpretation. At the same time, they also acknowledge other religious rights, through the dissemination of ideology, despite Islam being the official religion of Malaysia (Ali, 2015, 38). Conversely, the Malay integrity is rusted by the refusal of traditional practice, which does not go against the religious teaching. It was threatened by a certain anti-hadith movement stemming from the predominance of the heretics (ahl al-bida') and the popularity of their doctrines among young people (Tokatly, 2001, 60), as well as the cultural 
Published by Faculty of Islamic Civilization Studies, KUIS

assimilation influenced by Western civilisation that has threatened the younger Muslim generation.

\section{v. Feminism and its threat towards the Islamic family system}

Among the issues that have become causes for AHM is the gender bias discourse, in which they introduced a Western model as an alternative to the problems faced by Muslim women (Arat, 2000). They claimed that gender discrimination has become rampant in Malaysia, altogether giving a bad name to Islamic family social practices from a global perspective. The patriarchal culture (culture based on the dominance of the father) that was around for a long time among the Malay community is said to be oppressing women in society. This contrasts with the Malay society that prioritises the family institution being formed based on the noble values in Islam. The role of the father as the main educator in the family institution starts to be affected, following the concept that is individualistic, compared to the well-being of society and the nation as a whole.

\section{Conclusion}

Based on the discussion on liberalism put forth by AHM, it can be concluded that its development has its own place in the community, especially in urban areas. This is because the issues brought forth by AHM concentrate more on complex technical issues, causing it to be easily accepted and supported by highly educated people. It cannot be denied that the momentum produced by AHM is able to distract the strength of the society's belief system, especially when easy access to the mass media and social media is growing rapidly. Liberalism practices a sceptical attitude towards Islamic religious knowledge, and lowers the value and the role of the turath as the main valid source of Islamic teachings. By contrast, they greatly honour an aspect of Western civilisation that clearly leans on satisfying personal interests and needs, which reflects nafs that has plagued their souls. The sustainability of these Islamic beliefs is affected with the dissemination of liberalism, if it stays without defence and retaliation from the Muslim scholars themselves. Therefore, cooperation between the people in power and authority in religious institutions must play a role in ensuring the truthfulness in the system of belief and Shari' $a$ of Muslims in this country.

\section{References}

Abdul Rani, M. 2001. Gerakan Reformasi Gereja di Eropah dan Kesannya Terhadap Pegangan Seksualiti Masyarakat Barat. Jurnal Usuluddin, 14 (33-54).

Abou-Bakr, O. 2003. Teaching the Words of the Prophet: Women Instructors of the Hadith (Fourteenth and Fifteenth Centuries). Hawwa, 1(3), 306-328.

Adonis, A. 1994. Al-Thabit wa al-Mutahawwil. Beirut: Dar al-Saqir.

Ahmad, K. 1986. Hadis: Satu Penilaian Semula. Petaling Jaya: Media Intelek.

Ahmad, K. 1992. Hadis: Jawapan kepada Pengkritik. Kuala Lumpur: Media Indah Sdn. Bhd.

Al-Attas, S. 2007. Tinjauan Ringkas Peri Ilmu dan Pandangan Alam. Pulau Pinang: Universiti Sains Malaysia Press.

Ali, A. K. 2015. Anti-Hadith: Rujukan Kepada Kitab Jima' Al-'Ilm. Jurnal Usuluddin, 9(9), pp. 33-38. 
Alsehri, M. 2014. Western Works and Views On Hadith: Beginnings, Nature, and Impact. Marmara Üniversitesi Illahiyat Fakültesi Dergisi, 46(46), 203-224.

Alwi, E. A., Bakar, N. A., \& Subki, R. N. 2015. Heresy in Malaysia: An Analysis. Mediterranean Journal of Social Sciences, 6(2 S1), 463.

Anon. 2007. Kamus Dewan Edisi Keempat. Kuala Lumpur: Dewan Bahasa dan Pustaka.

Arat, Z. F. 2000. Women's Rights in Islam: Revisiting Quranic Rights. In. Adamantia Pollis \& Peter Schwab (Eds.) Human Rights: New Perspectives, New Realities. Colorado: Lynne Rienner.

Arkoun, M. 1994. Rethinking Islam. Boulder: Westview Press.

Aydin, C. 2007. The politics of anti-Westernism in Asia: visions of world order in pan-Islamic and pan-Asian thought. Columbia University Press.

Ayub, M. 2012. Qur'an, Hadith and Riba Connotation. Journal of Islamic Business and Management Vol, 2(2).

Bańkowska, A. 2007. Anti-Sunna opposition: Historical Perspective. Studia Arabistyczne i Islamistyczne, 13, 82-89.

Baraka, Y. R. \& Dalloul, Y. 2014. Building hadith ontology to support the authenticity of isnad. International Journal on Islamic Applications in Computer Science And Technology, 2(1), 25-39.

Bossy, J. 1970. The counter-reformation and the people of Catholic Europe. Past \& Present, (47), 51-70.

Brown, J. 2009. Hadith: Muhammad's Legacy in the Medieval and Modern World. Oxford: OneWorld Publications.

Brown, J. 2011. Is the Devil in the Details? Tension Between Minimalism and Comprehensiveness in the Shariah. Journal of Religious Ethics, 39(3), 458472.

Brown, J. 2013. Scripture in the modern Muslim world: the Quran and Hadith. In. Jeffrey T. Kennedy \& Ebrahim Moosa (Eds.). Islam in the Modern World. Abingdon: Routledge.

Buang, A. H. 2016. Fatwa Ajaran Sesat Dari Sudut Undang-Undang Dan Cabaran Pembanterasannya Di Malaysia. Journal of Fatwa Management and Research, 2(1).

Cameron, E. 2012. The European Reformation. Oxford: Oxford University Press.

Chadwick, O. 1990. The Penguin History of the Church: The Reformation. Vol. 3. United Kingdom: Penguin.

Choudhury, E. 2001. Virtue Ethics and the Wisdom Tradition: Exploring the Inclusive Guidance of the Quran. Global Virtue Ethics Review, 3(1), 26-26.

Daftary, F. 1984. Professor Asaf A. A. Fyzee (1899-1981). Arabica 31, no. 3: 327:330.

Darussamin, Z. 2016. Kassim Ahmad Pelopor Inkar Sunnah Di Malaysia. AlFikra, 8(1), 1-34.

Demirel, S. 2011. The impact of hadith perception on disputes between ahl al-Sunnah and al-Shi'ah al-Imamiyyah al-Ithna 'Ashariyyah. Intellectual Discourse, 19(2), 245.

Duderija, A. 2009. Evolution in the Canonical Sunni Hadith Body of Literature and the Concept of an Authentic Hadith During the Formative Period of Islamic ought as Based on Recent Western Scholarship. Arab Law Quarterly, 23(4), $389-415$. 
Published by Faculty of Islamic Civilization Studies, KUIS

Faridi, S. 1996. The Fallacies of Anti-Hadith Arguments. In. P. K. Koya (Ed.), Hadith and Sunnah: Ideals and Realities. Kuala Lumpur: Islamic Book Trust.

Farooq, M. O. 2014. Rejoinder to Muhammad Ayub's Qur'an, Hadith and Riba Connotation: A Critique of the Paper by Dr. Mohammad Omar Farooq'. Available

SSRN: https://ssrn.com/abstract=2429741 or http://dx.doi.org/10.2139/ssrn.2 429741

Fawcett, E. 2014. Liberalism: The Life of an Idea. New Jersey: Princeton University Press.

Fore, M. L. 2002. Shall Weigh Your God and You: Assessing the Imperialistic Implications of the International Religious Freedom Act in Muslim Countries. Duke Law Journal, 52(2), 423-453.

Fyzee, A. A. 2008. A Modern Approach to Islam. Oxford: Oxford University Press.

Gould, A. 1999. Origins of liberal dominance: State, church, and party in nineteenthcentury Europe. University of Michigan Press.

Hanafi, H. 1980. al-Turath wa al-Tajdid. Cairo: al-Markaz al-“Arabi li al-Bahth wa alNashr.

Herrera, L. 2004. Education, Islam, and modernity: Beyond westernization and centralization. Comparative Education Review, 48(3), 318-326.

Ismail, S. Z. 2010. Menangani ajaran sesat di kalangan umat Islam: Perspektif undang-undang dan pentadbiran. Jurnal Syariah, 18(2), 247-276.

Kadir, A., \& Othman, M. 2012. The major themes of Islam liberal in Selangor. Journal of Applied Sciences Research, 8(11), 5285-5289.

Karim, N. S. A., \& Hazmi, N. R. 2005. Assessing Islamic information quality on the Internet: A case of information about hadith. Malaysian Journal of Library and Information Science, 10(2), 51.

Khan, A. A. 2016. Islamic Culture and the Modern World-2. Defence Journal, 20(4), 49.

Kurzman, C. Liberal Islam: A Source-Book. Oxford: Oxford University Press.

Kymlicka, W. \& Opalski, M. 2002. Can liberal pluralism be exported?: Western political theory and ethnic relations in Eastern Europe. OUP Oxford.

Managheb, S. M., \& Mehrabi, A. 2013. Philosophical hermeneutic and its interaction with principles of Quran apprehension. International Research Journal of Applied and Basic Sciences. Vol, 7 (4): 232-242

Mayer, A. E. 2012. Islam and human rights: Tradition and politics. Hachette UK.

Müller, D. M. (2016). Paradoxical Normativities in Brunei Darussalam and Malaysia. Asian Survey, 56(3), 415-441.

Müller, D. M. 2015. Sharia Law and the Politics of "Faith Control" in Brunei Darussalam: Dynamics of Socio-Legal Change in a Southeast Asian Sultanate. In Internationales Asien Forum. International Quarterly for Asian Studies. Vol. 46, No. 3/4, p. 313.

Musa, A. Y. 2010. The Qur'anists. Religion compass, 4(1), 12-21.

Nagata, J. 1997. Ethnonationalism Versus Religious Transnationalism: Nation-Building And Islam In Malaysia. The Muslim World, 87(2), 129-150.

Nagata, J. 2004. Alternative models of Islamic governance in Southeast Asia: Neo-Sufism and the Arqam experiment in Malaysia. Global Change, Peace \& Security, 16(2), 99-114. 
Nagata, J., Lee, R. L., \& Ackerman, S. E. 1998. Sacred Tensions: Modernity and Religious Transformation in Malaysia. Crossroads: An Interdisciplinary Journal of Southeast Asian Studies, Vol. 12, No. 2 (1998), pp. 140-143.

Nasohah, Z., Laluddin, H., Kusrin, Z. M., \& Muwazir, R. 2012. Standardisation of fatwa in Malaysia: Management and problems. Advances in Natural and Applied Sciences, 6(6), 923-930.

Nazri, Z., et. al. 2016. Progressive Muslims' approach to Hadith texts: women issues in focus. In. Wanita Islam kontemporari: isu-isu, cabaran \& amalan terbaik. Persatuan Ulama' Malaysia, Shah Alam, Selangor Darul Ehsan, pp. 127-140.

Nordin, M. Z. F., Abdullah, S., \& Mansor, M. 2013. Religious liberalism in Sisters in Islam discourse: An analysis on identification. Proceeding of the International Conference on Social Science Research, ICSSR 2013. 4-5 June 2013, Penang, Malaysia, pp. 1047-1063.

Nurdin, A. A. 2005. Islam and State: A Study of the liberal Islamic network in Indonesia, 1999-2004. New Zealand Journal of Asian Studies, 7(2), 20.

Rahman, A. A., et. al. 2015. Istitabah Model for Apostasy Cases in Malaysia. 'Ulūm Islāmiyyah Journal, 15, 111-124.

Rahman, F. 2008. The Living Sunnah and al-Sunnah wal-Jama'ah. In. P. K. Koya (Ed.), Hadith and Sunnah: Ideals and Realities. Kuala Lumpur: Islamic Book Trust.

Saad, S. 1990. The legal and social status of women in the Hadith literature (Doctoral dissertation, University of Leeds).

Sabjan, M. A., \& Akhir, N. S. 2016. Reaksi Terhadap Pemikiran Anti Hadis Berdasarkan Karya Hadis: Jawapan Kepada Pengkritik. Jurnal Akidah dan Pemikiran Islam, 18(0).

Samuri, M. A. A., \& Hopkins, P. (2017). Voices of Islamic Authorities: Friday Khutba in Malaysian Mosques. Islam and Christian-Muslim Relations, 28(1), 47-67.

Shah, N. A. 2006. Women's human rights in the Koran: An interpretive approach. Human Rights Quarterly, 28(4), 868-903.

Sikander, E. 1991. Interpretation, revealed knowledge and the human sciences. Islamic Quarterly, 35(2), 77.

Spiegel, A. 2010. Mechanisms of Publicness: Dress, Cultural Belonging, and Education. In Contested Public Spheres (pp. 229-253). VS Verlag für Sozialwissenschaften.

Sudi, S., Wazir, R., Usman, A. H., Nasir, M. N., Ismail, Z., Salleh, S., \& Rahman, A. A. 2016. Sejarah Penulisan Hadis: Pembetulan Fakta Dari Hujah Anti Hadis. E-Proceeding of the 1st INHAD International Muzakarah \& Mu'tamar on Hadith, pp. 1-7.

Sulaiman, A., Jamsari, E. A., \& Nizah, M. A. M. (2013). Islam and the west: Critical perspectives on the position of the sunnah. Elixir International Journal, pp. 15084-15086.

Suliaman, I. 2009. Liberalisme dalam anti-hadis di Indonesia dan Malaysia. In. Islam Liberal: Isu dan Cabaran. Petaling Jaya: Persatuan Ulama Malaysia.

Syed, J., Özbilgin, M., Torunoglu, D., \& Ali, F. 2009. Rescuing gender equality from the false dichotomies of secularism versus shariah in Muslim majority countries. In Women's Studies International Forum. Vol. 32, No. 2, pp. 6779. Pergamon.

Tokatly, V. 2001. The A'lam al-hadith of al-Khattibi a commentary on al-Bukhiri's Sahih or a polemical treatise?. Studia Islamica, No. 92, pp. 53-91. 
Published by Faculty of Islamic Civilization Studies, KUIS

Wan Ramli, W. A. 2014. Menangani Cabaran Liberalisme dalam Kalangan Muslim Berdasarkan Konsep Ijmak. Jurnal Usuluddin, 40: 27-49.

\section{Author's Biography}

Abur Hamdi Usman, is a Ph.D. holder of Islamic studies at the National University of Malaysia. He received M.Phil and Ph.D in Sciences of the Qur'an. He was a student in the University of Al-Azhar. He has published numerous refereed articles on theology, Quranic exegesis, Hadith, Education and Islamic studies. His areas of interest include the Sciences of Quran and Hadith Studies. He travels and lectures widely. Currently, He is a Senior lecturer at International Islamic University College Selangor. He can be contacted at aburhamdi@kuis.edu.my. 